\title{
Verbal interventions of the National Bank of Ukraine: The impact of exchange rate
}

\author{
Kateryna Anufriieva \\ Department for Monetary Relations, Institute for Economics and \\ Forecasting National Academy of Sciences of Ukraine, \\ Ukraine \\ kateryna.anufrïeva@gmail.com \\ Yuliia Shapoval \\ Department for Monetary Relations, Institute for Economics and \\ Forecasting National Academy of Sciences of Ukraine, \\ Ukraine \\ shapovaljulia510@gmail.com
}

Abstract. This paper focuses on central banks' verbal interventions and takes a closer look at their impact on the exchange rate. As the main research methods, we chose statistical and sentiment analysis. The meaning of central banks' verbal interventions is examined by clarifying the importance of transparency for monetary policy. In order to understand the extent of the research, we present a review of the most outstanding examples of central banks' communication policies. The article assesses the transparency of the monetary policy of the National Bank of Ukraine (NBU) and generalizes foreign exchange-related indicators. The problem of expectations referred to the central monetary body, which influences communication policy, is also under consideration. We substantiate the interrelationship between the exchange rate and monetary policy trust indicators. The current research reviews regular and occasional groups of NBU's verbal interventions and outlines that business entities are focused on the exchange rate as the main factor of consumer goods' prices. We analyse the tendencies and effects of NBU's announcements on the exchange rate and as a result, reflect communication strategy priorities for Ukrainian central bank.

Keywords: monetary policy, central bank communication, verbal interventions, exchange rate, the National Bank of Ukraine.

JEL Classification: E3, E43, E44, E52, E58 


\section{INTRODUCTION}

The need to increase the transparency of monetary authorities' policies over the past decades has led to development of the communication channels aimed to achieve understanding and targeted response of market participants. This feedback is usually reflected in the activities, and in planning and risk assessment by local, foreign and international economic agents, which may cause the exchange rate movements, and which should be considered in monetary policies.

Cooperation with supranational organizations has become the push to increase the transparency of central monetary authorities in developing small economies, including Ukraine. The best practices for transparency are set out in the Code of good practices on transparency in monetary and financial policies (Code, 1999) of the Interim Committee, led by the IMF, in 1999. They presuppose compliance with two basic principles: achieving policy effectiveness is possible in the case of public awareness of policy goals and instruments, and implementing the policy in case of commitment by the relevant authority. According to the IMF Code, transparency is an environment in which the objectives of policy, its legal, institutional, and economic framework, policy decisions and their rationale, data and information related to monetary and financial policies, and terms of accountability are provided to the public on an understandable, accessible and timely basis. Transparency rests upon the clear central bank's role, reporting of monetary policy decisions by the central bank and informing on monetary and financial policies. Transparency of the goals and policy instruments, aligned with the authorities' credible commitment to meeting them and their good governance (meaning authorities' accountability), strengthens the effectiveness of monetary and financial policies and promotes potential efficiency of markets. At the same time, moral hazard, market discipline and financial market stability considerations may justify limiting the disclosure of information. The NBU shall prioritize the stability of Ukrainian currency as well as price stability according to the respective Law of Ukraine "About the National Bank of Ukraine" No. 679-XIV as of 20.05.1999. As such, the NBU is responsible for presenting to governing authorities the estimations of currency and exchange rate policies' indicators including the average-year, end-year and three-year exchange rate, publishing data essential for financial market players, except for the state or banking sensitive information. According to the declared IMF-Ukraine Memorandum of Economic and Financial Policies (as of 5.12.2018), the NBU is committed to reserve the floating exchange rate regime and to set the official exchange rate on a daily basis according to the predefined procedure.

Development of central bank communications has been analysed by a variety of researchers, still, there is a need to understand better risks and benefits of their implications for monetary policy, as central banks, including the NBU, seek to continue their progress towards greater transparency.

This paper is dedicated to the study of the hypothesis that the central banks' communication influences the exchange rates.

The structure of the article is as follows: section 2 provides literature review on the issues of central banks' statements effects. Section 3 describes the methodological approach applied in this article. Section 4.1 focuses on the generalization of communication approaches with the reference to the world practice. Section 4.2 analyses the interrelations between transparency of monetary policy and trust to the central bank in case of Ukraine. Further, section 4.3 throws light on the NBU's verbal interventions and exchange rate. Finally, the last section presents conclusions and main recommendations of the article.

\section{LITERATURE REVIEW}

The issues of the monetary policy transparency and the effects of central banks' communication on macroeconomic and financial variables are sufficiently covered. In particular, D. Jansen and J. Haan (2005) confirm that verbal interventions are used to support the effectiveness of "physical" interventions 
in the foreign exchange market and to broadcast information on the upcoming monetary policy direction, which is directed towards the currency market and changes its expectations accordingly. Along with that, these researchers (Jansen \& Haan, 2006) point out that communication may also hamper the correct prediction of the policy decisions due to communication dispersion. J. Haan (2008) has revealed that if communications steer expectations, asset prices should react and policy decisions should become more predictable. Using statements by euro area central bankers as reported by Bloomberg, scientists found that inconsistent communication on the inflation outlook coincides with greater uncertainty regarding upcoming ECB interest rate decisions. After GFC in terms of challenges in unconventional times (high economic uncertainty, constrained policy instruments, an introduction of new policy instruments) A. S. Blinder et al. (2017) have traced that central banks in crisis countries are more likely to resort to new policies, to discuss mandates, and to communicate more. However, the thinking has changed more broadly: central banks in non-crisis countries also report to have implemented macroprudential measures. L. Sarno and M. Taylor (2001) stated that the signaling channel assumes that intervention affects exchange rates by providing the market with new relevant information, under the implicit assumption that the authorities have superior information to other market participants. The state bodies are also willing to reveal this information through their actions in the foreign exchange market.

Economists H. Leon and O. Williams (2012) highlighted the importance of interventions to support external competitiveness, to curb imported inflation and to maintain the short-term stability of the exchange rate in emerging economies. In his turn, M. Fratzscher (2005) investigated the short-term effect of interventions and argued that interventions also had a medium- and long-term impact. The economist presented an alternative methodology based on the study of interventions in the Eurozone, the USA and Japan since 1990. That was aimed at analysing the long-term effectiveness of interventions, according to which verbal and physical interventions should not be considered separately, and exchange rate reports are effective regardless of physical interventions and monetary policy. L. Burkhard and A. Fischer (2007) argued that if the central bank speaks clearly, its statements could affect a variety of asset prices in nonnegligible ways. While financial market reactions depend on the details of the communications, especially their timeliness and news content, central bank talk apparently contains news, which is quickly incorporated into asset prices. The findings of J. Allard et al. (2012) indicate that the ECB communicates intensively on fiscal policies in both positive as well as normative terms. The other central banks more typically refer to fiscal policy while describing foreign developments relevant to domestic macroeconomic developments, using fiscal policy as input to forecasts, or referring to the use of government debt instruments in monetary policy operations. The empirical analysis also indicates that the financial crisis has overall increased the intensity of central bank communication on fiscal policy. C. Conrad and M. Lamla (2007), focusing on the impact of ECB communication on the euro-dollar exchange rate, have constructed communication indicators for the introductory statement and found that communication with respect to future price developments is most relevant. M. Galardo and C. Guerrieri (2017) have proven that verbal guidance is an effective policy instrument for signalling an accommodative monetary policy stance. C. Engel and K. West (2006), by exploring the link between an interest rate rule for monetary policy and the behaviour of the real exchange rate, outlined that based on the reaction of the exchange rate the central bank's policy function can be examined. Thereby, it can be outlined, how a central bank conducts monetary policy.

While the Ukrainian literature traditionally deals with issues of transparency of central bank monetary policy, the more specific issue of verbal interventions has so far received very little attention. The problem of NBU's communication policy has been considered in the Ukrainian research only in the recent decade.

In general, Ukrainian scientists recognize the key role of improving NBU's communication strategy to increase the effectiveness of conducting monetary policy. In that manner, O. Petryk (2008) 
analysed the order of disclosure of information by global central banks, applying the regime of inflation targeting. He stressed that a well-functioning effective communication system of the central bank is required to achieve price stability. O. Petryk proved that the most important part of the communication system of the NBU should be the preparation of the inflation report presentation. The peculiarities of the NBU's communication policy were singled out, in particular, controversial surveys of enterprises and communication with the government, the president, and the parliament. In view of this, A. Zakutnyaya (2017) has improved the methodological approach to modeling the connection between the quality of inflation reports and the expectations of financial market participants regarding the size of the discount rate and proposed a mechanism for the formation of transparent environment for the implementation of the monetary policy. According to her conclusions, the NBU's communication policy strategy should take into account the peculiarities of the socio-economic situation in the country and the level of financial literacy of the population. The regular measures of direct communication with society should be implemented using the most ranking media for this purpose. Based on the scientific study of $\mathrm{H}$. Bereslavska (2010) with the example of the policy of the NBU, one can conclude that the communications of the central monetary authority are an important part of the policy to maintain financial stability and regulation of the banking sector. Their effect is to reduce uncertainty in the financial market. $\mathrm{H}$. Bereslavska (2010) stressed the importance of trust in the appropriate authority, backed by institutional determinants of the effectiveness of its policy. Elaborating on the specifics of Ukrainian monetary system R. Holub and O. Hlushchenko (2017) developed the methodical approaches to improve the central bank's communication strategies, based on the use of its verbal interventions and smoothing out the excessive cyclical volatility of exchange rates of the national currency. V. Vyshnevskyy et al. (2017) note that there is precisely the lack of mutual trust in Ukraine, the absence of "long" rules of behaviour, and cases of nonprofessional actions of the officials that takes fundamental financial and economic decisions. Associated therewith, an unfavourable institutional environment is one of the main challenges facing the monetary mechanism of the Ukrainian economy.

Further to the above findings, the current research assumes and gives factual proof that the exchange rate remains the influential indicator, which is disclosed in central bank communication. We take into account that Ukrainian economic agents are most vulnerable to the exchange rate estimations. Thereby we justify the NBU communication channels in conditions of the lack of exchange rate guidance for financial planning and budgeting. We assume that a "forward-looking" exchange rate forecast function is of high importance, whereas a "backwards-looking" exchange rate explanations lead rather to exchange rate volatility in the central bank verbal interventions.

\section{METHODOLOGY}

The main objective of this article is to give affirmation to the hypothesis that the content of verbal interventions affects the exchange rate in the case of the Ukrainian economy.

In this article, we used methods of grouping and comparison to generalize the practice of global central banks' communications and types of NBU's verbal interventions; expert assessments to determine its transparency and disclosure of foreign exchange-related indicators; correlation, statistical and sentiment analysis to study the interrelations between NBU's communication channels and the exchange rate through the prism of trust to monetary policy. In order to explain the connections, we took indicators such as the number of announcements on the NBU's website, exchange rates of hryvnia, discount rate, international reserves, $\mathrm{M} 0$, core consumer inflation, and business expectations.

The data, statistically analysed in Excel, were taken from the publicly available sources. 


\section{EMPIRICAL RESULTS AND DISCUSSION}

\subsection{Central banks' communications as part of monetary policy: world practice}

In frames of the researched verbal interventions, the definitions include interventions, communications, and signals. Within the marketing subject, communication strategy is "a holistic planning approach to engaging [...] audience to ensure greater effectiveness" (Murphy, 2015, p. 4). Another source referring to marketing communications says that this is a management process to engage audiences by recognizing the different transactional and relationship needs of the target audience, and "can be used to engage with a variety of audiences in such a way that one-way, two-way and dialogic communications" (Fill et al., 2014, p. 12). Within the financial science field, P. Gertler and R. Horvath (Gertler et al., 2017, p. 2) outlined that "verbal communication has been a traditional tool of central bank" and being "both official and ad-hoc [...] is becoming an important pillar of monetary policy framework". These authors indicated the novel features of central bank communication. "Central banks started to communicate financially (in)stability issues more intensively. In consideration of the implementation of unconventional monetary policy measures, the content of verbal communication widened, financial markets have become much more complex and integrated with non-negligible international spillovers. Taking into account the limited fiscal space in the global economy, more attention has turned to central banks to combat the crisis".

Practitioners use a number of communication channels, and we can pick up the following channels for our purpose (Pearson, 2016):

- those grouped by territory scope are local, national, international channels;

- those arranged by means of communication include print, broadcast, website (reports, pressreleases, databases, infographic), blogs and twitter, event-dedicated (conferences, seminars, speeches, i.e. in the Parliament) and direct communication with the press;

- those classified by the audience are the channels directed at state authorities, creditors and investors, businesses, households, other special interest groups.

Taking the case of monetary relations, communication has become a complementary tool to achieve the objective of higher transparency containing the following:

- adherence to the reporting demands of supranational organizations (e.g. the IMF) and international creditors;

- explanation and justification of the authority decisions according to the demands of the changing internal economic and social as well as financial market conditions and external challenges;

- financial education of society.

Communication policies differ by country. The Federal Reserve System (Fed) and the European Central Bank (ECB) are open to recommendations and are trying out the transparency tools to regain public trust (Koranyi, 2017). On the opposite to their "guidance for action", the People's Bank of China (PBoC) withholds from any comment about its monetary policy in general and about actions impacting currency market and moreover keeps silence about any further forward-looking statements. Actions of the $\mathrm{PBoC}$, e.g. changing interest rates' and loans' limits, and lending to the state institutions are rather a "rumour-communication" than direct communication policy. Latter is vividly witnessed by the example of so-called quantitative easing (QE) in China in 2011: "whereas central banks in developed economies have explained every step of their QE schemes to markets, the PBoC did not even bother to announce its activity" and merely "acknowledged the operation, though declined to say how much it had lent, at what rate or even to which bank" (The Economist, 2014). After that, PBoC has slightly opened the veil of the upcoming decisions about its liquidity injections in 2013 (Ro, 2014), still mostly being non-transparent 
about its decisions, e.g. not publishing full meeting minutes, which caused currency devaluation. China regulator's silence can well be the outcome of limited operational independence from the state. A recent Barclay's survey ranked the PBOC third-worst of 14 big central banks in terms of communication, behind only Turkey's and Russia's (The Economist, 2014) (Table 1).

Table 1

Monetary policy and exchange rate follow-ups in the global central banks' communications

\begin{tabular}{|c|c|c|c|c|}
\hline Central bank & Instrument & $\begin{array}{l}\text { Explaining } \\
\text { monetary } \\
\text { policy and } \\
\text { exchange rate- } \\
\text { related } \\
\text { decisions }\end{array}$ & $\begin{array}{l}\text { Publishing meeting } \\
\text { minutes }\end{array}$ & $\begin{array}{l}\text { Communicating } \\
\text { outlook on } \\
\text { monetary policy- } \\
\text { related indices } \\
\text { and/or guidance }\end{array}$ \\
\hline ECB & $\begin{array}{l}\text { Press releases, Government } \\
\text { Council decisions, press } \\
\text { conferences, monetary policy } \\
\text { accounts, speeches, } \\
\text { interviews, webcasts }\end{array}$ & Yes & $\begin{array}{l}\text { Yes (monetary } \\
\text { policy accounts) }\end{array}$ & Yes \\
\hline Fed & $\begin{array}{l}\text { Press releases, speeches, } \\
\text { testimony, videos }\end{array}$ & Yes & Yes & Yes \\
\hline Bank of Japan & $\begin{array}{l}\text { Outlines, speeches and } \\
\text { statements, reports, releases }\end{array}$ & Yes & Yes & $\begin{array}{l}\text { Forecasts on } \\
\text { economic activity } \\
\text { and prices } \\
\text { (inflation) }\end{array}$ \\
\hline $\mathrm{PBoC}$ & Reports, speeches & No & No & No \\
\hline $\begin{array}{l}\text { Central Bank of the } \\
\text { Russian Federation }\end{array}$ & $\begin{array}{l}\text { Decisions (on discount rate), } \\
\text { interviews, speeches }\end{array}$ & Yes & $\begin{array}{c}\text { No (only } \\
\text { announcements } \\
\text { and speeches, not } \\
\text { minutes) }\end{array}$ & $\begin{array}{c}\text { Forecasts on } \\
\text { inflation, petroleum } \\
\text { prices }\end{array}$ \\
\hline $\mathrm{NBU}$ & $\begin{array}{l}\text { Press releases, comments, } \\
\text { speeches }\end{array}$ & Yes & $\begin{array}{c}\text { Yes (press-releases, } \\
\text { results of } \\
\text { discussions) }\end{array}$ & Yes \\
\hline
\end{tabular}

Source: Compiled by authors based on central banks' official websites.

\subsection{Transparency and trust in the central bank' monetary policy: Ukrainian practice}

According to widely-spread Dincer and Eichengreen's index (Figure 1), the monetary policy of the NBU is not sufficiently transparent. The clarity of the NBU's activities has slightly increased in recent years, but in terms of transparency of monetary policy, Ukraine still lags behind the Eastern European countries, similar in economic development and increase in disclosure requirements and attempting to reach high standards of monetary policy. On the other hand, since 2015, significant progress has been made in regular publications by posting analytical materials on the official website. During the latest 3 years, the activity of the NBU in social networks (Twitter, YouTube, Facebook, Flickr, and Instagram) and on its own web page has increased to a large extent. By the way, $0,074 \%$ of the population follow the NBU's Facebook page, created on July 3, 2014 (Lepushynskyi, 2018, p. 21). 


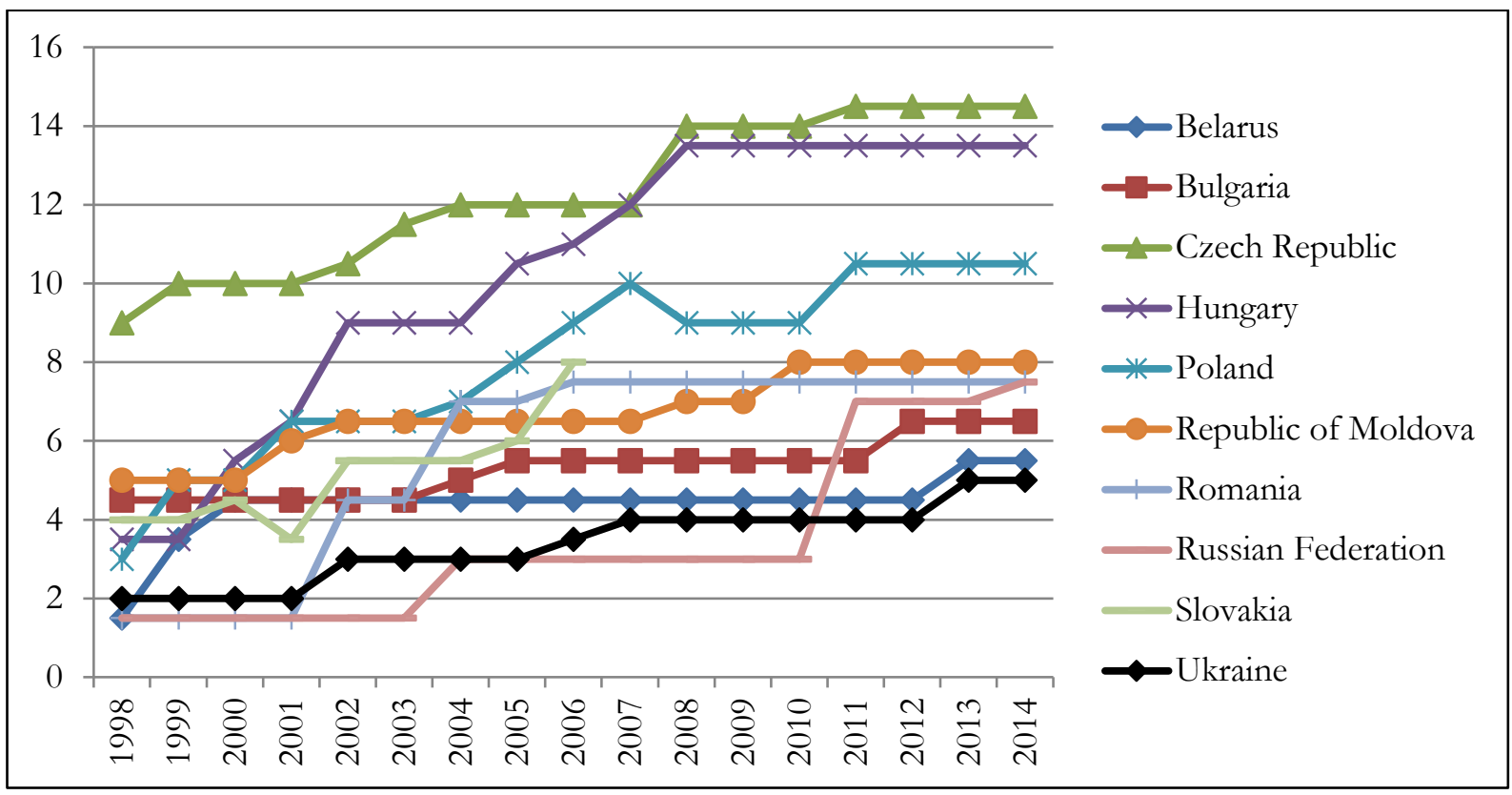

Figure 1. Dincer and Eichengreen ${ }^{1}$ central bank transparency index of Eastern Europe countries, $1998-2014$

Source: Compiled by authors based on (Dincer \& Eichengreen, 2014).

At the same time, cooperation with the IMF helped to upturn the NBU's transparency. The growth of NBU's institutional independence was launched with the legislative initiative - the law of Ukraine "On amendments to certain legislative acts of Ukraine on the development of the institutional capacity of the NBU" No. 541-VIII dated 18.06.2018. The reporting requirements in frames of Ukraine-IMF relations declared in the Memorandum of economic and financial policies section IV, obliged the NBU to disclose a number of data, including foreign exchange sales, interventions, export proceeds, on import transactions for goods and services, transfers, the balance of payments data. In other words, information influencing or showing the stance of the currency market and the exchange rate is communicated to the public, i.e. through the website (Table 2).

Another issue is the level of trust and expectations referred to the central monetary body, which affects the communication policy. Economists state that public distrust in Ukraine is a great obstacle. In recent world rankings, Ukraine has made the biggest progress on the openness of data, budgets, and government, which is a mechanism that will help raise trust ${ }^{2}$.

In the case of the NBU, there were attempts to estimate the level of trust to the central bank's monetary policy and to the Ukrainian banking system. The shares of bank FX loans and deposits are quite

${ }^{1}$ Dincer and Eichengreen calculate measures of central bank transparency for more than 120 countries based on 5 broad criteria: political, economic, procedural, policy, and operational. Based on these measures of central bank transparency, inflation-forecast-targeting central banks are the most transparent in the world, achieving close to a maximum score of 15 .

2 According to R. Sheremeta's experimental model of a complex financial market with a high degree of uncertainty, asymmetric information, etc. Person 1 provided Person 2 with funds, and in turn, Person 2 could provide funds to Person 3. There were incentives to give the money, but there was also a risk because the participants did not know who would use their funds and how. In addition, the more transparent the market became, the more trust the players had. When the curtain was completely lifted, there was the highest level of trust and the highest rate of efficiency of such a market (Sheremeta, 2018, August 27). 
large (in 2018: $43 \%$ and 42\% respectively). In turns, the natural dollarization ratio meeting the individuals' and business need for the use of the hard currency for affecting of the external economic activity and hedging currency risks should be at the approximate $20 \%$, considering the hryvnia depreciation for the past five years. Anyway, cash share remains at the point near 30\% in $2014-2018$, which might implicitly mean that the economic agents deliberately keep the liquid money as the base for the cash currency speculations. The ratio of financing of 3,4 months of imports by the reserves in 2018 compared to 1,4 in 2014 also defines how much hard currency the NBU has to secure for the foreign exchange expenses related to the flow of imports (National Bank of Ukraine). Central monetary authority mentions these indicators in the verbal messages that may influence the expectations of the exchange rate direction.

Table 2

Foreign exchange-related indicators reported by the NBU to the IMF

\begin{tabular}{|c|c|c|}
\hline Indicator & $\begin{array}{l}\text { Frequency of } \\
\text { reporting }\end{array}$ & Availability on the website \\
\hline Obligatory, voluntary and total foreign exchange sales & Daily & $\begin{array}{c}\text { Partial (total FX sales; only rates of } \\
\text { obligatory FX sales) }\end{array}$ \\
\hline Foreign exchange $(\mathrm{FX})$ interventions & Daily & Yes \\
\hline Foreign exchange export proceeds & Daily & $\begin{array}{c}\text { Partial (can be extracted from the } \\
\text { balance of payments, not on daily } \\
\text { basis) }\end{array}$ \\
\hline Results of foreign exchange auctions & Daily & Yes \\
\hline $\begin{array}{l}\text { Balances in the analytical accounts } 2900 \text { "Accounts } \\
\text { payable per transactions for the foreign exchange, } \\
\text { banking and precious metals purchase and sale on } \\
\text { behalf of banks' clients" }\end{array}$ & Daily & No \\
\hline Data on import transactions for goods and services & No & Yes \\
\hline $\begin{array}{l}\text { Data on amounts of FX transferred from abroad to the } \\
\text { benefit of physical persons-residents } \\
\text { And non-residents - to be paid in cash without } \\
\text { opening an account, data on FX wires from Ukraine } \\
\text { abroad for current FX nontrade transactions on the } \\
\text { basis of the orders } \\
\text { Of physical persons }\end{array}$ & No & $\begin{array}{l}\text { Partial (FX wires from Ukraine } \\
\text { abroad) }\end{array}$ \\
\hline $\begin{array}{l}\text { Data on sales and purchases of foreign exchange cash } \\
\text { by individuals }\end{array}$ & No & Yes \\
\hline $\begin{array}{l}\text { Volumes of noncash FX purchases on behalf of banks' } \\
\text { clients and banks broken down by reasons }\end{array}$ & Weekly & $\begin{array}{c}\text { Yes (total, without a breakdown by } \\
\text { reasons) }\end{array}$ \\
\hline $\begin{array}{l}\text { The balance of payments data in electronic format } \\
\text { within } 80 \text { days after the end of the quarter }\end{array}$ & Quarterly & Yes \\
\hline
\end{tabular}

Source: Compiled by authors based on (National Bank of Ukraine, International Monetary Fund).

In the sphere of the international relations, sanctions and ratings also influence the level of trust and communication strategies of the monetary regulators. Since 2014, Ukraine has become the new hot spot for the national and supranational regulatory bodies imposing financial sanctions. These added to depreciation factors of the hryvnia exchange rate and caused interruptions in bank settlements each time when Ukraine is indicated as a destination in a payment order or as a party or country of operation, (e.g. US OFAC called its sanction program "Ukraine-/Russia-related sanctions"). Therefore, Ukraine appeared on the stop- or block-lists of global banks (United States Government). Another related factor, the assigned estimates by the international rating agencies, impact the level of trust to the national currency itself as well as to the central monetary authority and to the communication strategy of the latter. 
Among the foremost trust-related indicators in Ukraine, that the economic agents take into account is the national currency exchange rate dynamics. That is proved by a survey conducted in December 2017, by the "Social Monitoring" centre and the O. Yaremenko Ukrainian Institute of Social Studies along with the Department of the Monitoring Studies of Socio-Economic Transformations of the Institute for Economics and Forecasting (where the methodology and questionnaire were developed). The survey received about 55,1\% meaningful responses (of the population representing adult population of Ukraine) on whether respondents know the current UAH/USD exchange rate as the highest awareness rate compared to other macroeconomic indicators. The Ukrainians' subjective level of awareness for the macroeconomic indicators other than exchange rate was $-20,7 \%$ for the average wage at the regional level; $20,4 \%$ for the average wage at the country level; $10,7 \%$ for inflation rate and $9,7 \%$ for the unemployment rate. The study defined explanations of the high level of awareness about the USD exchange rate, which includes linkage to consumer prices, hryvnia turbulence, highly-available sources of information, and its role of a proxy for inflation. The results also have stated that the adult population of Ukraine as a whole is poorly aware of the values of the listed macroeconomic indicators with the only important exception of the USD exchange rate. The authors outlined that the close attention to the exchange rate would witness lack of trust to the national currency. Given the exchange rate is a simple proxy for households and its expectations with strong positive correlation with the inflation assessments (Titar, 2018), the use of possibilities to influence exchange rate estimation might have positive externalities for inflationary expectations as well as for households' behaviour.

The popularity of the websites, which distribute news and dynamics of the exchange rate, checked regularly by population and being, the largest "market competitors" in the search engine optimization rankings, also confirm public interest. Such websites as finance.i.ua, banker.ua, kurs.com.ua are among the population references, where one can examine the content in order to "compose" the proper message to the market. According to the NBU website core statistics, most of the visitors including foreign, presumably creditors and counterparties, watch the pages with the official daily and historical averageperiod exchange rate (Figure 2). Thus, verbal interventions through the internet source are gaining momentum.

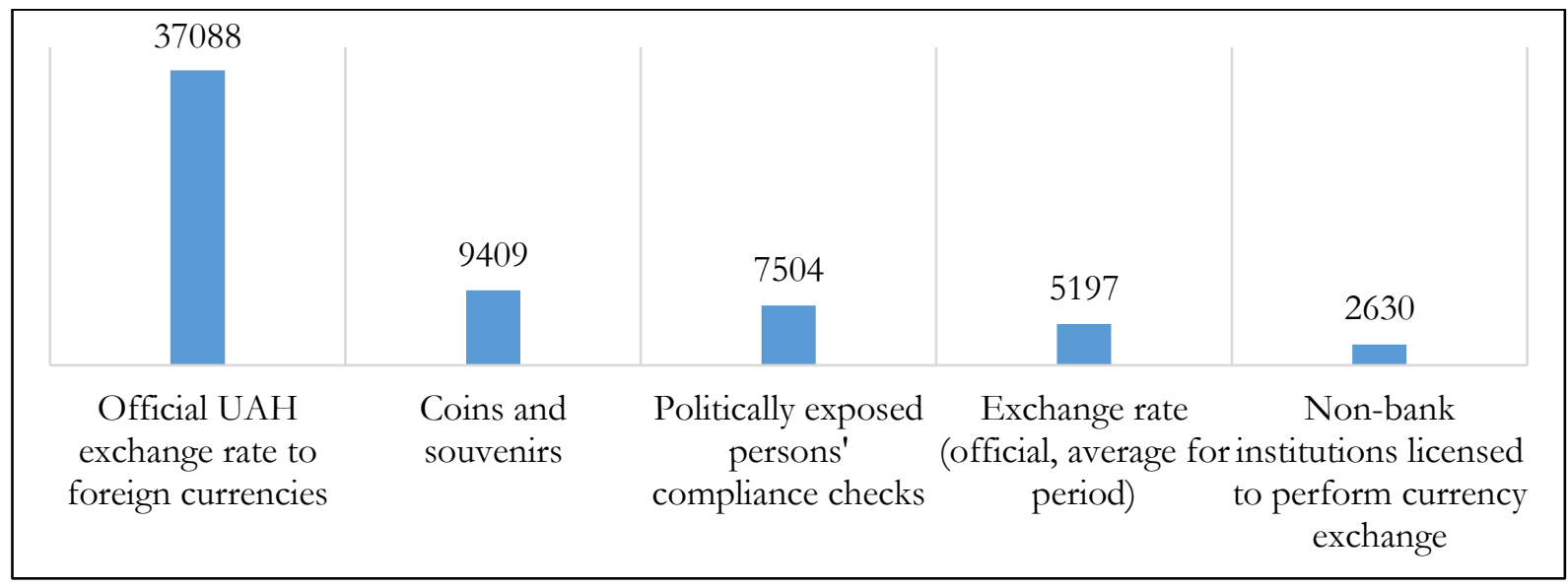

Figure 2. The NBU website pages by popularity, as on the end of May 2019

Source: Compiled by authors based on (Serpstat)

The NBU analyses business expectations of the exchange rate tendency (depreciation, stable for no change and appreciation) in the context of consumer goods prices' change factors (Figure 3). Since the $1^{\text {st }}$ quarter, 2014 businesses re-focused on the exchange rate as the main factor of consumer goods' prices 
versus production expenses' factor that predominated earlier. In the $4^{\text {th }}$ quarter of 2008 , through the $4^{\text {th }}$ quarter 2009, i.e. during the financial and economic crisis in Ukraine, the exchange rate factor also took the prevalent position. Moreover, the preponderating weight of exchange rate change expectations, meaning if businesses await appreciation, stability or depreciation, refers to depreciation anticipated throughout most of the analysed period (the National Bank of Ukraine).

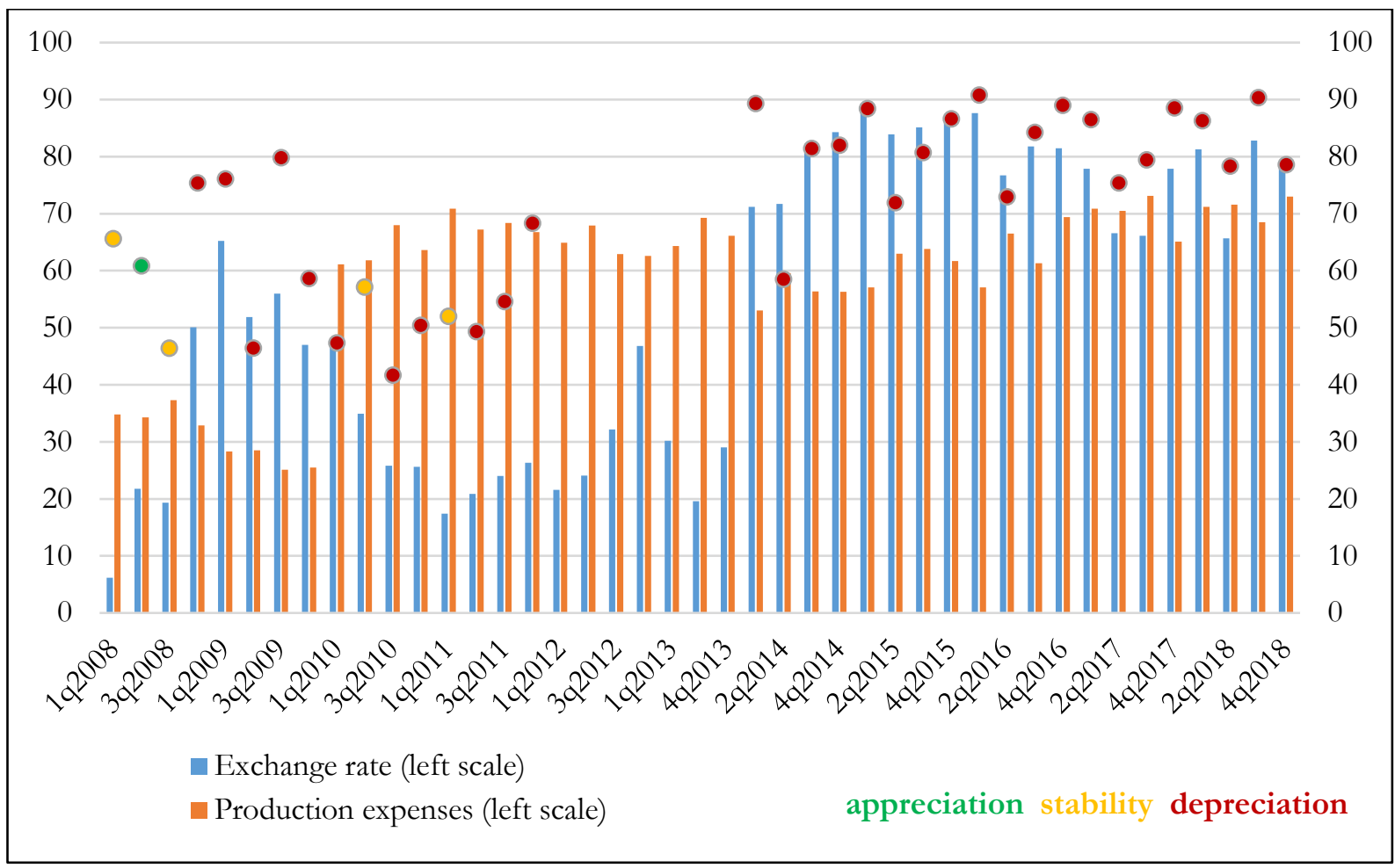

Note: The only reporting periods, when appreciation and stability were expected, are marked by green and yellow filled circles respectively.

Figure 3. Consumer goods prices' change factors of Ukrainian corporate sector expectations (percentage), $2008-2018$

Source: Compiled by authors based on (National Bank of Ukraine).

As measured, there is a positive correlation of $0.08-0.26 \% \%$ between the exchange rate and the dynamics of the indicators distributed in the regulator's communication, such as changes in the discount rate, international reserves' stock, cash in vault and core consumer inflation (which excludes positions exposed by temporary shocks) (Figure 4). As proof checked by the t-criteria, we revealed that the correlation is statistically significant only for the core consumer inflation. The discount rate in its turn is calculated by the central bank based on the analysis and development forecast of the macroeconomic and financial data, which also includes consumer inflation. Therefore, we can assume that communication and explanation of these parameters by the regulator may influence the exchange rate expectations. 


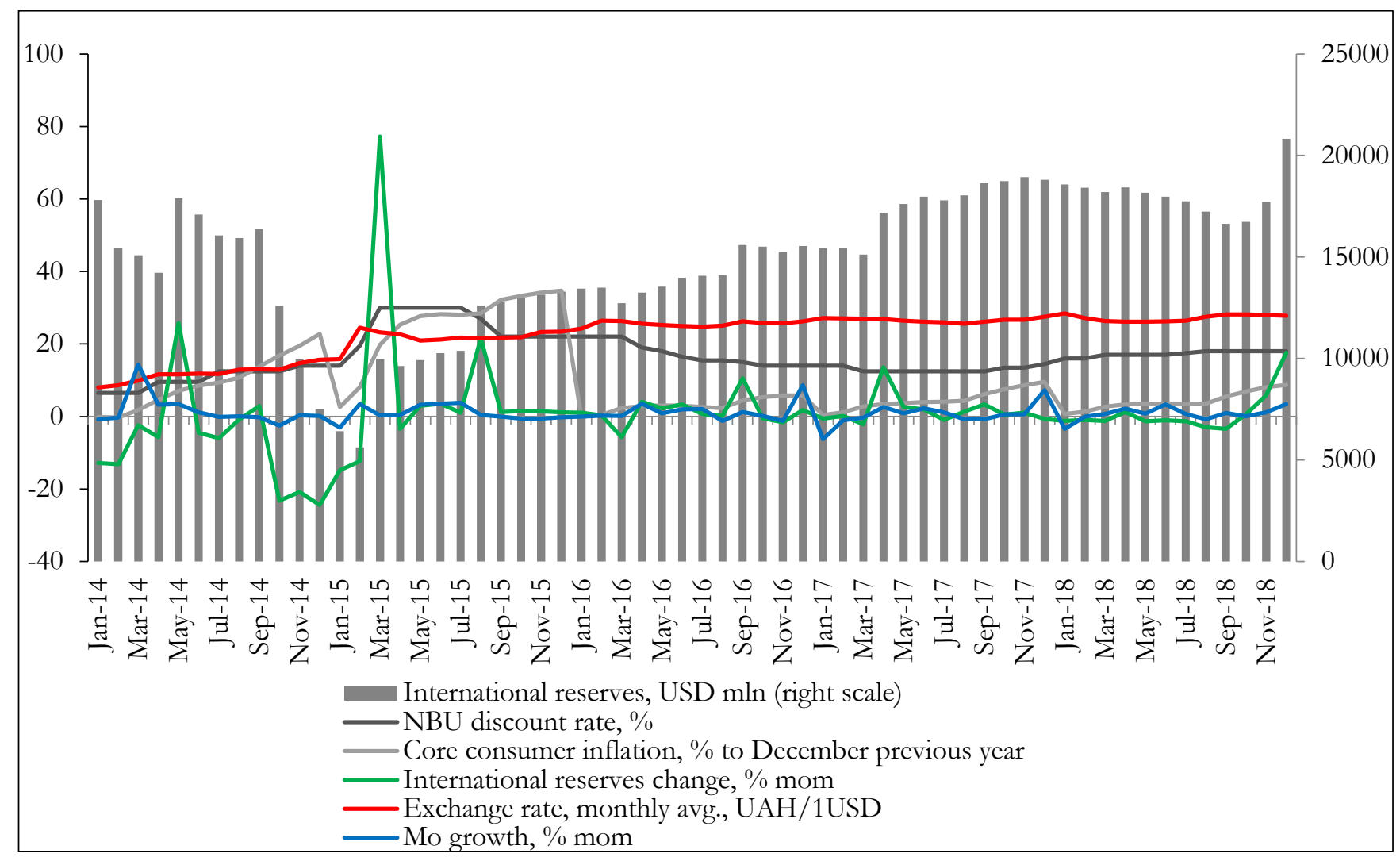

Figure 4. The main economic parameters, communicated by the NBU, January 2014 - December 2018

Source: Compiled by authors based on (National Bank of Ukraine).

\subsection{The NBU's manner of the verbal interventions concerning the exchange rate}

We pointed out two groups of NBU's verbal interventions. Regular interventions include press briefings (following the results of scheduled meetings), statistics about foreign exchange market (daily), publications ((inflation reports (quarterly), macroeconomic and monetary reviews (monthly), inflation reviews (monthly), monetary and financial statistics (monthly), and business outlook surveys (quarterly)), while occasional interventions consist of interviews, columns for the magazine, articles, lectures, presentations, info days, and press-tours (Figure 5). By the way, the "Inflation Report" published quarterly since 2015 reflects the macroeconomic forecast and its underlying assumptions concerning exchange rate, taking into account that the NBU switched to a flexible exchange rate regime in 2014. The disclosed foreign exchange risk indicates how far the currency market trends can affect the financial performance of banks. Upon that, NBU's verbal interventions concerning exchange rate are made in conjunction with other comments on monetary policy. Among regular verbal interventions, there are press releases used most often, and answers to mass media used occasionally. 


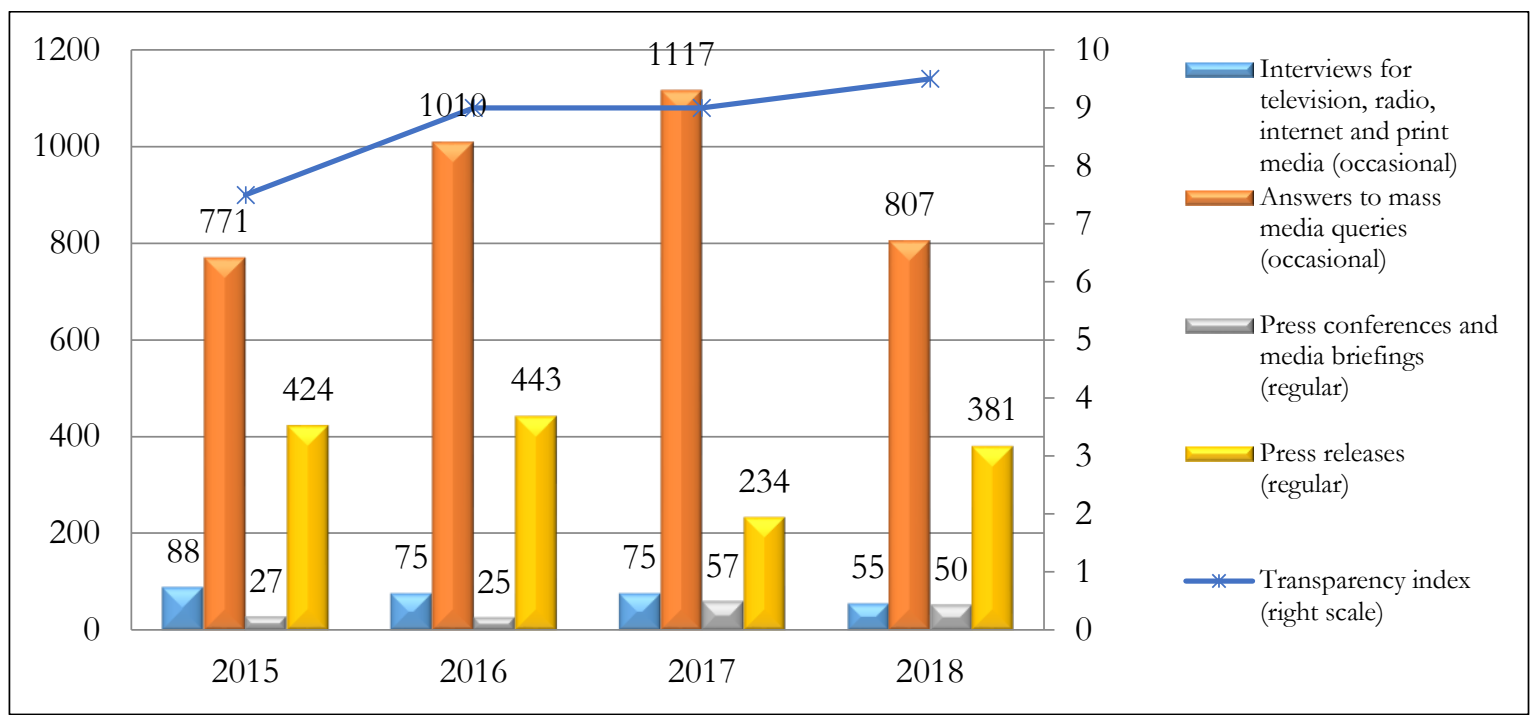

Figure 5. Transparency index and communication channels of NBU, $2015-2018$, numbers Source: Compiled by authors based on (National Bank of Ukraine).

The time to update official hryvnia rates for foreign currencies on the official NBU's website is also a kind of verbal intervention. In particular, earlier, the NBU used to announce rates every day after lunch, and they began to work at 2:00 p.m., but since March 21, 2015, exchange rates are published at the end of the working day until 6:00 p.m. (from August 1, 2018 - before 4:00 p. m) and begin to take effect from the next working day. However, the above-mentioned adjustments, together with the latest introduction of the new method of calculating the official hryvnia exchange rate, cannot actually reduce the expectation of devaluation. This prevents market players from using the rate as a benchmark for the currency market.

News about "international donors' assistance to Ukraine" is also a verbal intervention of the central bank in the Ukrainian practice. According to Table 3, the market and the exchange rate reacts with stabilization effect $(\downarrow)$ only to an announcement like "Ukraine will receive assistance" or "Completion of IMF's mission", while verbal interventions that contain only intentions or the start of action make no effect $(\leftrightarrow)$.

Table 3

Exchange rate and international donors' assistance to Ukraine, 2014 -2018

\begin{tabular}{|c|c|c|}
\hline Date & The announcement on NBU's website & $\begin{array}{l}\text { The trend } \\
\text { of } \\
\text { exchange } \\
\text { rate }\end{array}$ \\
\hline \multicolumn{3}{|l|}{2018} \\
\hline December 18 & $\begin{array}{l}\text { The approval by the IMF Executive Board of a new program of cooperation with } \\
\text { Ukraine under a Stand-By Arrangement (SBA) }\end{array}$ & $\downarrow$ \\
\hline September 14 & Ukraine will receive from the EU macro-financial assistance -1 billion euros & 1 \\
\hline September 13 & NBU continues to work with international donors & 世 \\
\hline August 13 & $\begin{array}{l}\text { The arrival of the IMF mission to Ukraine is a step towards reducing uncertainty } \\
\text { and improving expectations }\end{array}$ & $\uparrow$ \\
\hline April 23 & $\begin{array}{l}\text { Ukraine and the IMF discussing the terms of the fourth review of the cooperation } \\
\text { program }\end{array}$ & $\uparrow$ \\
\hline \multicolumn{3}{|c|}{ (5 } \\
\hline September 13 & $\begin{array}{l}\text { The NBU Board met with David Lipton, First Deputy Managing Director of the } \\
\text { IMF }\end{array}$ & $\leftrightarrow$ \\
\hline
\end{tabular}




\begin{tabular}{|c|c|c|}
\hline \multicolumn{3}{|l|}{2016} \\
\hline December 19 & The NBU strengthens its partnership with ECB & 个 \\
\hline November 18 & NBU comment on completing the mission of the IMF & $\downarrow$ \\
\hline September 15 & The third tranche of the IMF will replenish the international reserves of the NBU & \\
\hline September 8 & $\begin{array}{l}\text { Restoration of cooperation with the IMF will improve macro-financial stability in } \\
\text { Ukraine }\end{array}$ & $\downarrow$ \\
\hline June 17 & $\begin{array}{l}\text { The NBU held a meeting of the coordinating committee of international donors in } \\
\text { Ukraine }\end{array}$ & $\downarrow$ \\
\hline February 10 & NBU's comment on cooperation with the IMF & $\uparrow$ \\
\hline \multicolumn{3}{|l|}{2015} \\
\hline December 10 & The NBU met the International Donors Committee of Ukraine & $\uparrow$ \\
\hline February 27 & Extract from the quotation of the speaker of the IMF & \\
\hline February 12 & $\begin{array}{l}\text { The IMF announces an agreement with the Government of Ukraine on a new } \\
\text { program, the EFF of } 17,5 \text { billion USA dollars }\end{array}$ & \\
\hline \multicolumn{3}{|c|}{ t } \\
\hline 22 December & $\begin{array}{l}\text { The IMF assessed the intentions of the Ukrainian authorities to take decisive steps } \\
\text { to stabilize the economy }\end{array}$ & \\
\hline August 8 & $\begin{array}{l}\text { The World Bank allocated } 500 \text { million USA dollars to improve the banking system } \\
\text { of Ukraine }\end{array}$ & \\
\hline July 18 & $\begin{array}{l}\text { V. Gontareva and N. Georgiev announced the results of the IMF mission in } \\
\text { Ukraine }\end{array}$ & \\
\hline June 25 & $\begin{array}{l}\text { A working meeting of the leadership of the NBU with representatives of the } \\
\text { mission of the IMF }\end{array}$ & \\
\hline May 8 & $\begin{array}{l}\text { Receipt of the first tranche of IMF loan increased gold and forex reserves to } 17,30 \\
\text { billion USA dollars }\end{array}$ & \\
\hline April 11 & $\begin{array}{l}\text { Approval of the IMF program and the implementation of economic reforms will } \\
\text { help stabilize the exchange rate }\end{array}$ & $\downarrow$ \\
\hline March 27 & $\begin{array}{l}\text { S. Kubiv and N. Georgiev announced preliminary agreements reached on the } \\
\text { program of economic reforms and granting loans to Ukraine under the stand-by } \\
\text { program }\end{array}$ & 个 \\
\hline March 26 & EU is ready to continue providing macro-financial support to Ukraine & $\uparrow$ \\
\hline March 14 & $\begin{array}{l}\text { The head of the NBU and representatives of the IMF mission discussed the } \\
\text { preliminary results of the work }\end{array}$ & $\hat{\imath}$ \\
\hline March 7 & $\begin{array}{l}\text { The head of the NBU S. Kubiv held a working meeting with representatives of the } \\
\text { IMF mission }\end{array}$ & $\uparrow$ \\
\hline March 5 & $\begin{array}{l}\text { The Head of the NBU discussed with the representatives of EU the possible } \\
\text { financial support of Ukraine }\end{array}$ & $\downarrow$ \\
\hline March 4 & The head of the NBU met with the IMF mission & $\downarrow$ \\
\hline
\end{tabular}

Source: Compiled by authors based on (National Bank of Ukraine).

Another verbal intervention is the assigned estimates by the international rating agencies, which correct the level of trust to the national currency itself as well as to the central monetary authority and to the communication strategy of the latter. Since 2013, the disclosure of the negative macroeconomic forecasts and Standard \& Poor's, Fitch Ratings, Moody's ratings of the Ukrainian economy with an upward trend affect the growth of the exchange rate.

The quantity of NBU's official comments on the situation in the FX market is not sufficient, especially for our vulnerable market (Figure 6). These messages are late to be effective, and as a result, the exchange rate only increases. 


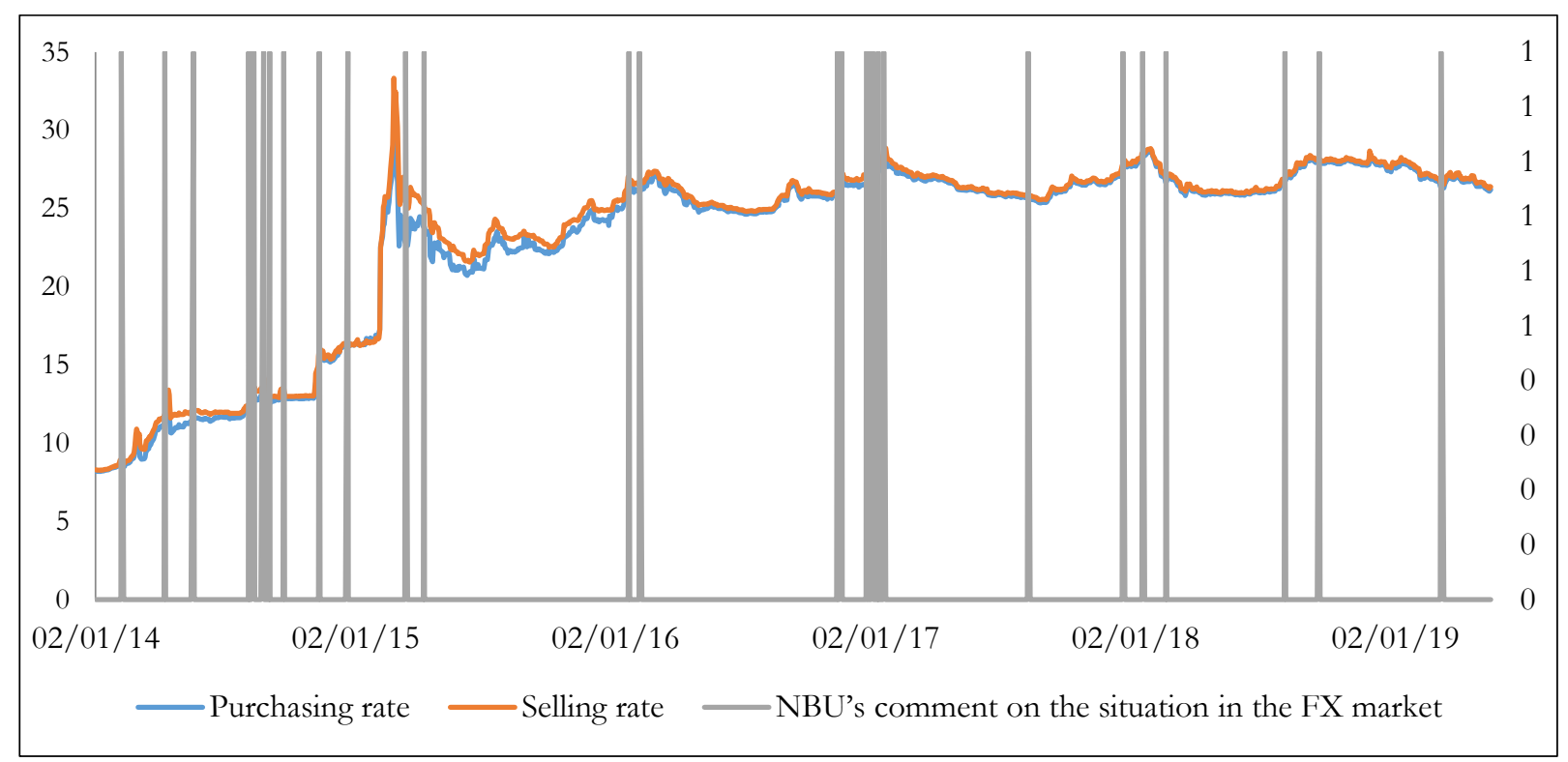

Figure 6. Frequency of NBU's comment on the situation in the FX market and daily exchange rate on the foreign exchange cash market of Ukraine, 2014 - May 2019

Source: Compiled by authors based on (NBU).

The historical overview of the NBU's verbal interventions has shown the most frequent mentioning of the exchange rate within the context of any regulatory changes of the central bank or any events that might among other things influence the exchange rate dynamics.

In such a situation, verbal interventions within the well-designed communication strategy should become the influential complimentary instrument of the central monetary authority. The communication strategy, in general, considers the before mentioned level of trust to a certain personality (e.g. NBU governor) and to the institution of the NBU as the basis; to the warning term (early or later warning) as well as to the frequency to coincide with business cycles, terms of foreign trade, administrative decisions and political developments. The strategy also regards the target audience, taking into consideration what should be disclosed and what is kept confidential, along with different effective communication methods for population versus businesses (Figure 7).

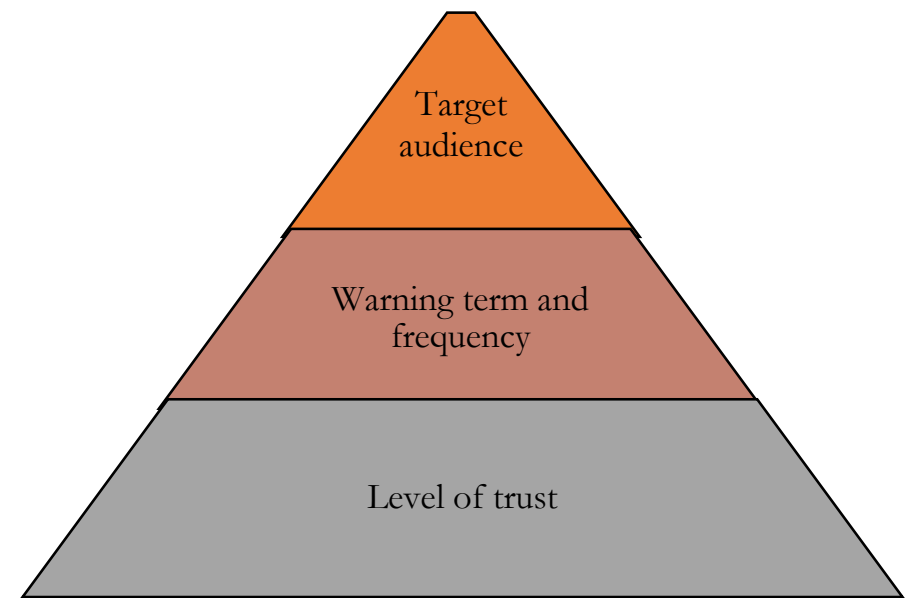

Figure 7. Communication strategy priorities Source: Compiled by authors based on (Murphy, 2015). 
In the vulnerable macroeconomic conditions, the absence of exchange rate predictability leads to the impossibility of conducting the forecast financial and economic activity by the economic entities, and to limited exchange rate estimability causing in its turn capital outflow (Moskalyuk, 2015). The above substantiates the necessity to develop novel instruments to withhold severe exchange rate fluctuations, increase its response to the central bank policies and goals, and thus its predictability under the limited effectiveness of monetary levers. That is why the discount rate has not yet become a guiding landmark. It performs its action merely in central bank refinancing operations, as well as in view of lacking means for material interventions. Exchange rate development can be assessed with a variety of approaches, comprising periods (e.g. 2008 - 2009, 2009 - 2013, periods since 2014), and political events and central bank actions, including those intended to introduce amendments to the exchange rate regime. Political events will apparently play a critical part in Ukraine. The last two currency crisis episodes in 2008 and 2014 revealed the strong need for the NBU to have the structured and predefined communication strategy to tackle the unpredictability fear and guide market expectations during periods of speculative attacks on the hryvnia.

Export opportunities were hampered by trade wars with Russia and related sanctions, and by the cease of exports from main mining regions involved in the military conflict. The above clears up that exchange-rate-related variable may fail to either properly respond to the regulator's actions or allow forecasting the real and expected hryvnia value. This substantiates the outstanding need for the creating of well-organized communications related to the central monetary actions, which may include providing messages to the market on certain actions, variables and any changes within the body's powers.

The kaleidoscope of political events and changing the NBU governors each bringing regulatory novelties with respect to monetary policy, and particularly to the currency market and exchange rate, as well as the macro-conditions in the country, require an arrangement of a breakdown of the verbal communications affecting or referring to the exchange rate by a range of criteria. The last one should contain the following: a period of action of the NBU governor, political events, state of the economy, and monetary market developments.

\section{CONCLUSION}

The objective of the paper is to demonstrate the impact of NBU's verbal interventions on the exchange rate.

Our results point out a direct relationship between central bank verbal interventions and exchange rate volatility, which is an important factor influencing inflation and output growth in Ukraine. The disclosure of the negative macroeconomic forecasts and the international ratings of the Ukrainian economy with an upward trend affects the growth of the exchange rate.

The findings indicate that recently the NBU communication policy has undergone remarkable changes. The NBU has become more transparent since 2015, but so far, "forward-looking" exchange rate forecast function lacks and communication is rather of a "backwards-looking" and "explanatory" nature. Moreover, the central bank does not seem to have a clear communication strategy embedded in the actual practice.

Even though the use of the experience of other central banks in verbal interventions could give the opportunity to increase the efficiency of monetary policy, the established international practice shows the following. Communication approach should be tailored to national specificities, and the ideal method simply does not exist. That is why there is a need to develop and implement the own Ukrainian model of the strategy of verbal interventions usage. The NBU should adopt a decisive communication approach with clear communication objectives, well-targeted messages for different target audiences and appropriate 
verbal interventions channels. In particular, the NBU must constantly inform the participants of the national currency market about the deviation of the current exchange rate from its established level at a certain point in time.

Lastly, we would like to emphasize that effective verbal interventions concerning national currency trends with the public would increase the transparency of monetary policy, keeping in mind that the ability of the NBU to affect the inflation depends on its ability to influence market expectations about the future path of the exchange rate.

\section{REFERENCES}

Allard, J., Catenaro, M., Vidal, J. P., \& Wolswijk, G. (2012). Central bank communication on fiscal policy. ECB

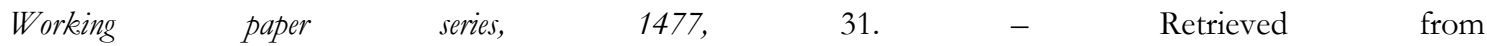
https://www.ecb.europa.eu/pub/pdf/scpwps/ecbwp1477.pdf.

Bereslavska, H. (2010). Monetary policy in Ukraine: theory and practice. University of the State Fiscal Service of Ukraine, 330.

Blinder, A., Ehrmann, M., Haan, J., \& Jansen, D. (2017). Necessity as the mother of invention: monetary policy after the crisis. ECB Working paper series, 2047, 60. Retrieved from https://www.ecb.europa.eu/pub/pdf/scpwps/ecb.wp2047.en.pdfabe7bf104544fa3b8ba9be1bb85c6ef2.

Burkhard, L., \& Andreas Fischer, M. (2007). Communicating Policy Options at the Zero Bound. Swiss National Bank Working papers 2007-12, $39 . \quad$ Retrieved from https://www.snb.ch/n/mmr/reference/working_paper_2007_12/source/working_paper_2007_12.n.pdf.

Code of Good Practices on Transparency in Monetary and Financial Policies (1999) International Monetary Fund. Retrieved from https://www.imf.org/external/np/mae/mft/code/index.htm.

Conrad, C., \& Lamla, M. J. (2007). The High-Frequency Response of the EUR-US Dollar Exchange Rate to ECB Monetary Policy Announcements. KOF Working papers 07-174, 42. doi: 10.3929/ethz-a-005476100

Dincer N., \& Eichengreen, B. (2014). Central bank transparency and independence: updates and new measures. International Journal of Central Banking, $10 \quad$ (1), 189-253. Retrieved from https://www.ijcb.org/journal/ijcb14q1a6.pdf.

European Central Bank. Webcasts of press conferences. Retrieved from https://www.ecb.europa.eu/press/tvservices/webcast/html/index.en.html.

Engel, C., \& West, K. D. (2006). Taylor Rules and the Deutschmark: Dollar Real Exchange Rate. Journal of Money, Credit and Banking, Blackwell Publishing, 38(5), 1175-1194. doi:10.1353/mcb.2006.0070

Fill, C., \& Jamieson, B. (2014) Marketing Communications. Edinburgh Business School, 33. Retrieved from https://www.ebsglobal.net/EBS/media/EBS/PDFs/Marketing-Communications-Course-Taster.pdf.

Fratzscher, M. (2005). How successful are exchange rate communication and interventions? Evidence from timeseries and event-study approaches. ECB Working paper series 528, 60. Retrieved from https://www.ecb.europa.eu/pub/pdf/scpwps/ecbwp528.pdf.

Galardo, M., \& Guerrieri C. (2017). The effects of the central bank's verbal guidance: evidence from the ECB. Temi di discussione (Economic working papers) 1129, $74 . \quad$ Retrieved from https://www.bancaditalia.it/pubblicazioni/temi-discussione/2017/2017-1129/en_tema_1129.pdf.

Gertler, P., \& Horvath, R. (2017). Central Bank Communication and Financial Markets: New High-Frequency Evidence, 336-345. Retrieved from http://macro.soc.uoc.gr/docs/Year/2017/papers/paper_3_116.pdf.

Haan, J. (2008, December). The effect of ECB communication on interest rates: An assessment. The Review of International Organizations, Springer, 3(4), 375-398. doi: 10.1007/s11558-008-9048-z.

Holub, R., \& Hlushchenko, O. (2017). Communication strategy optimization within the framework of impact on exchange rate expectations of economic agents. Economies, MDPI, 5(3), 1-15. doi:10.3390/economies5030033

International Monetary Fund. Retrieved May 1, 2019 from https://www.imf.org.

Jansen, D., \& Haan, J. (2005). Were Verbal Efforts to Support the Euro Effective? A High-Frequency Analysis of ECB Statements. DNB Working Papers 033, 19. Retrieved from https://www.nbp.pl/konferencje/2june/jansen_dehaan.pdf. 
Jansen, D., \& Haan, J. (2006). Look who's talking: ECB communication during the first years of EMU. International Journal of Finance \& Economics, 11(3), 219-228. doi: 10.1002/ijfe.294.

Koranyi, B., \& Lawson, H. (2017, March 28). ECB needs greater oversight, accountability: watchdog. Reuters. Retrieved from https://www.reuters.com/article/us-ecb-transparency-idUSKBN16Y2LV.

Leon, H., \& Williams, O.H. (2012). The effectiveness of intervention in a small emerging market: an event study approach. Applied Financial Economics, Taylor \& Francis Journals, 22(21), 1811-1820. doi: 10.1080/09603107.2012.681024.

Lepushynskyi, V. (2018). Communication, Transparency, and Accountability of Monetary Policy. National Bank of Ukraine, 31. Retrieved from https://bank.gov.ua/doccatalog/document?id=71289883.

Moskalyuk, N. (2015). Monetary levers of exchange rate stabilization in Ukraine. Efektyuna ekonomika, 10. Retrieved from http:/ /www.economy.nayka.com.ua/?op=1\&z=4549.

Murphy, G. (2015). Communication Strategy: A Best Practice Guide to Developing Communication Campaigns, 17. Retrieved from http://www.thegoodpitch.com/wp-content/uploads/2011/09/CommunicationsStrategyGuide.pdf.

National Bank of Ukraine. Retrieved May 1, 2019 from https://www.bank.gov.ua.

Pearson, V. (2016). Writing a communications strategy. The University of Oxford, 28. Retrieved from https://www.ox.ac.uk/sites/files/oxford/media_wysiwyg/Writing $\% 20 \mathrm{a} \% 20$ communications $\% 20$ strategy $\% 2$ $0 \% 2818.02 .16 \% 29$.pdf.

Petryk, O. (2008). The path to price stability, international experience, and perspectives for Ukraine. University of Banking of the National Bank of Ukraine, 369.

Ro, S. (2014). China's Central Bank Did Something Unusual Today. Business Insider. Retrieved from https://www.businessinsider.com/chinas-central-bank-communication-2014-1.

Sarno, L., \& Taylor, M. (2001). Official Intervention in the Foreign Exchange Market: Is It Effective, and, If So, How Does It Work? Journal of Economic Literature, XXXIX, 839-868. Retrieved from https://www.cass.city.ac.uk/_data/assets/pdf_file/0008/40697/sarno_taylor_jel.pdf.

Serpstat. Retrieved May 1, 2019 from https://serpstat.com.

Sheremeta, R. (2018, August 27). Public distrust in Ukraine is a catastrophe. VoxUkraine. Retrieved from https://voxukraine.org/en/public-distrust-in-ukraine-is-a-catastrophe-the-interview-with-roman-sheremeta.

The Economist (2014, November 20). The People's Bank of China Covert operations. Retrieved from https://www.economist.com/finance-and-economics/2014/11/20/covert-operations.

Titar, I. (2018, June 20). MacroIgnorance: Which Economic Indicators. VoxUkraine. Retrieved from https://voxukraine.org/uk/makroneviglastvo-v-yakih-ekonomichnih-pokaznikah-oriyentuyutsya-ukrayintsi/.

Ukraine: Letter of Intent, Memorandum of Economic and Financial Policies, and Technical Memorandum of Understanding (2016), 74. Retrieved from https://www.imf.org/external/np/loi/2016/ukr/090116.pdf.

United States Government. Ukraine-/Russia-related Sanctions. Retrieved October 31, 2018 from https://www.treasury.gov/resource-center/sanctions/Programs/pages/ukraine.aspx.

Vyshnevskyy, V., Vyshnevskaya, E., Matyushyn, A., \& Sheludko, N. (2017) Monetary power in the modern world. Who will challenge the dollar?. PH Akademperiodyka, 200. doi: 10.15407/akademperiodyka.345.200.

Zakutnyaya, A. (2017). The development of monetary policy on the basis of forming a transparent environment for its implementation. Sumy State University, 24. Retrieved from http://essuir.sumdu.edu.ua/handle/123456789/51454. 